\title{
Corporate Regulation and Corporate Governance of Small Businesses in Australia
}

\author{
Kumudini Heenetigala, Anona Armstrong and Andrew Clarke \\ Victoria University, Australia
}

\begin{abstract}
This paper presents the results of a study of small business owner/managers and CEOs of industry associations in relation to corporate regulation and corporate governance for small businesses in Australia. It is part of a larger project investigating regulation and small business governance supported by an Australian Research Council grant and COSBOA. A survey of the CEOs of small business associations and small business owner/managers investigated the corporate governance practices of small businesses, their understanding of their duties as directors, their approach to managing risks and accountability, the regulatory difficulties experienced by small businesses, and the factors that inhibited or promoted the performance of small business.
\end{abstract}

\section{Kew words}

small business, governance, regulation

\section{Introduction}

Small Businesses are referred to as the 'engine room of the Australian economy' (Clarke, A., 2007) because of the major role they play in the economic and social wellbeing of Australia. Even though they comprise $96 \%$ of all firms, employing more than 5 million people (National Office for the Information Economy, 2007), in the past, their regulatory needs were largely ignored because regulation is aimed at large listed firms. This was particularly true in respect to the Corporations Act. However, the sequence of disasters affecting businesses in Australia, natural disasters such as droughts and floods and economic flow-on from the impacts of the GFC, have drawn attention to the role of small business in stimulating the national economy. One consequence is that governments are increasingly seeking ways of both reducing the burden of regulation on small corporations (Miller, 1010; Deighton-Smith 2008) and using regulation to enhance their efficiency and contribution to the national economy .

This paper presents the results of a study of small business owner /managers and CEOs of industry associations in relation to corporate regulation and corporate governance for small businesses in Australia. It is part of a larger project investigating regulation and small business (Armstrong et al 2004) supported by an Australian Research Council grant. 


\section{Definition of Small Business}

Regulators and scholars are yet to agree upon a simple definition of a small corporation, however, they do agree that small corporations can include: one person firms, family firms/ businesses (Romano and Smyrnios 1996; Spender 1997), SMEs (small and medium enterprises), and small proprietary companies (Cassidy, 2005). The range of small corporations is therefore numerous and complex. Their legal structure is classified as sole proprietors, partnership or a company. Even though a variety of criteria are employed to define a small business (eg. total net worth, relative size within the industry, number of employees, value of products, annual sales or receipts and net worth), for the purpose of this research we used the definition derived from s 45A(2) Corporations Act 2001 (Cth). According to this definition:

- Small companies are those with less than 50 shareholders which meet at least two of the following criteria:

- consolidated revenue of less than $\$ 25$ million per year;

- gross assets of less than $\$ 12.5$ million;

- fewer than 50 full-time employees.

\section{Regulation}

Regulation is defined as a principle rule or law, designed to control or govern (Bank, 2006), and considered an essential component of governing. The OECD (1997)\} defines regulation more broadly as "the diverse instruments by which governments set requirements on enterprises and citizens". Regulations include laws, formal and informal orders and subordinate rules issued by all levels of government, and rules issued by non-governmental or self-regulatory bodies to which governments have delegated regulatory powers. In the past, regulation was aimed at large listed firms and the regulatory needs of small businesses were largely ignored. This is particularly true in respect to the Corporations Act. Furthermore, small businesses are also more affected by red tape than large companies. This is because they are less proficient in dealing with regulation because of its complexities and their limited resources. They are unable to spread the costs of compliance across large scale operations (Chittenden et al, 2003) and, due to the fixed-cost nature of the regulation, it creates an environment, where the regulatory costs are disproportionately borne by small businesses (Green, 2002)

\section{Corporate Governance and Small Business}

Corporate governance is concerned with internal structures and processes for decisionmaking, accountability, control and behaviour at the top of organisation (Clarke, A. 2004), and external mechanisms for accountability (Armstrong et al 2011). Therefore corporate governance is mainly about the control and direction of companies, exercised by their directors or those holding power and authority, and any decision making in all those matters which affect the vision, performance and long term sustainability of an organisation.

The Corporations Law refers to a "Director" as those legally appointed and responsible for the duties and responsibilities of directors. However, the owners and managers of small corporations see themselves as owners and managers rather than as directors (Armstrong et al 2011). 
When the roles of management and ownership are located in the same person, an agency problem does not emerge. The agency problem refers to the potential conflict of interests between owners and managers (Jensen and Meckling 1976). In large organisations owners provide finance via investment and allocate control to managers who then end up with discretion about how to allocate the investors' funds. Agency theory suggests that the self interest motivating managers can be in conflict with the profit maximising interests of investors. Governance mechanisms, such as an independent board and directors, are seen as a means of separating decision making from the risks of operations and thereby limiting a manger's self serving behaviour (Eisenhardt, 2004; Fama and Jensen 2004).

Many small businesses are managed by only one or two persons, mainly the owners and/or managers, who make all the critical decisions on finance, accounting, personnel, purchasing, processing or servicing, marketing, selling without the aid of internal specialists and with specific knowledge in only one or two areas (Wiltshire Committee, 1971). For them governance is a combination of views of the owners and the manner in which they run the business \{Burgess et al, 2009 \#132\}. Burgess contends that small businesses are concerned with improving their performance and allowing the commensurate benefits to flow to stakeholders such as owners and employees. Many are not interested in economic growth, but rather battle survival on a day to day basis and aim to provide themselves and their employees with a comfortable living (Burgess and Hill, 2004). Others seek a certain life style and autonomy not available when employed in a large organisation.

Governance of small businesses differs significantly from larger corporations in respect of size, resources, level of employment, directors' perceptions of their role, decision making authority, family business structures, independence of board chair and CEO/manager, use of independent directors, diversity and accountability Armstrong et al 2010). Many are family companies that, as they grow in size, face different problems, such as those of succession and minority shareholder rights (Kanpathanat and Armstrong, 2011).

\section{Governance and Regulation}

The purpose of regulation of corporate governance is to reduce risk and maintain order and confidence in the corporate capital market and to safeguard the investments of shareholders. These include both direct owners of shares and secondary owners such as those contributing to social and financial institutions such as superannuation funds (Armstrong et al, 2011). The purpose of regulation from a government perspective is to maintain the social order. Regulation of governance includes both internal and external governance mechanisms. Internal mechanisms are the system or structure of rules and relationships, supervision and control of those who exercise the authority, accountability, stewardship, leadership, direction and control which aim to ensure accountability and efficient use of resources in balancing the achievement of goals of corporations, society and individuals (Armstrong 2004).

External governance mechanisms, such as the Corporations Law and rules for listed companies imposed by the Australian Securities Exchange, guide the internal governance of a company. The main differences in the Corporations Law between the regulation of large and small companies are the level of disclosure and the requirement for large companies to produce formal audited accounts (Adams, 2010). Furthermore, an alternative to complying with the main provisions of the Corporations Law were a section in the Act referring to small business and adoption of the Replaceable Rules to guide internal governance mechanisms such as meeting procedures (Francis and Armstrong 2009).. 
External governance mechanisms are those imposed from outside the organisation most notably, government regulation. As a result, governance and regulation are intimately related.

\section{Regulation of corporate governance practices in small corporations}

In the context of this study, corporate governance refers to the provisions of the Corporations Act, particularly Laws for: Replaceable Rules, simplification for the regulation of small businesses, formation and structure of a board, the appointment and independence of directors and Best practice governance as recommended by the ASX guidelines. Best practice guidelines recommend boards with independent directors, the separation of ownership and control, appropriate skills and diversity of directors, succession plans, a code of conduct ,record keeping and information disclosure.

Adams (2009) describes a major distinction that relates to the level of disclosure required by the regulators and the requirement to produce formal accounts and auditing. A small proprietary company under s 292(2) generally does not have to provide a financial report nor a directors' report unless there is a direction (request) from the shareholders (s 293) or ASIC (s 294). However, all companies, including small proprietary companies have an obligation to keep financial records under s 286 Corporations Act 2001 (Cth). The financial records must correctly record and explain all transactions and the financial position of the company and would enable a true and fair financial statement to be prepared. The records must be kept for seven years and it is a strict liability criminal offence to fail to keep such records. This obligation is in addition to any tax law provisions.

Apart from the above, small businesses must also comply with tax regulations, superannuation, health and safety, environmental laws etc.

\section{The purpose of the study}

This aim of this paper is to report on a study of corporate regulations and corporate governance in relation to small businesses which investigated the views of small business owner /managers and CEOs of industry associations in relation to corporate regulation and corporate governance for small businesses in Australia. Although previous research had investigated the relevance of the corporate law to small business, there was a gap in the research in relation to the perceptions of and practices of governance in small corporations and the impact of governance regulation on small business performance.

The research questions were:

- What were the corporate governance practices of small businesses? Did they have boards of directors? Did they understand their duties as directors? How did they manage their risks? Were they publicly accountable?

- Were the roles of owners/and managers combined?

- What were the corporate governance and regulatory difficulties experienced by small businesses?

- What factors inhibit or promote the performance of small business?

\section{Methodology}

In order to assess the corporate regulations and corporate governance of small businesses, this study employed both quantitative and qualitative techniques. This study was part of a larger study, supported by an Australian Research Council (ARC) grant and COSBOA, that investigated the responsiveness of governance regulation in small businesses in Australia (Armstrong et al. 2011). The sample for this study was twenty one participants consisting of nine owner/managers of small businesses and twelve executive directors of small business industry associations in Victoria. 
The sample was a purposive sample selected because of their in-depth knowledge and experience of small business. The majority of the small business respondents in this study were male $(77.7 \%)$ and $22.2 \%$ were female. The highest level of education achieved by the participants was a bachelors degree $(33.3 \%)$ and $22.2 \%$ had post graduate qualifications and a further $22 \%$ had secondary education. Over $50 \%$ in this sample were technically qualified.

Interviews were conducted using a structured interview schedule containing both closed and open ended questions. The opinions and experiences of respondents were reported on a 1-7 likert scale and responses were probed for in-depth explanations. This gave participants the opportunity to provide comments as well as raise issues that would be useful in the analysis and provide insight into the issues.Most of the survey was conducted by telephone although a few respondents opted to email or mail their responses to the surveys. The quantitative data were analysed using SPSS to produce descriptive statistics and qualitative data were content analysed. The following section will discuss the results of the analysis.

\section{Results}

\section{Respondents Views of Corporate Governance Practices of Small Corporations}

\section{Constitutions and Replaceable rules}

The replaceable rules are a model set of internal arrangements to follow if a corporation does not have its own constitution. Two thirds of the small businesses had their own constitution. Three used the Replaceable Rules. However, in general, respondents were not familiar with the Rules and left all governance matters to their accountants.

\section{Board Structure}

The results showed that few of the small businesses operated with a board and sub-committees were rare.

Furthermore, they did not have any independent directors and little separation of the management and board. $\quad$ For many small businesses, a board was reported as 'not applicable' or not necessary. A board became necessary when a company had more than one shareholder or grew to the stage of appointing a separate manager.

Six of the CEOs of Industry associations reported that less than a quarter of their members have a board of directors. Only one association, the largest, reported that all their members had a board in place. Three estimated between $25 \%$ to $49 \%$, of their members have a board of directors. One respondents disclosed that more than $50 \%$ of their members have a board of directors. Of the 9 small businesses, 3 had a board of directors and the other 6 had no board. Two of the respondents whose corporation had a board which had 3 directors and 1 reported that they had 1 director.

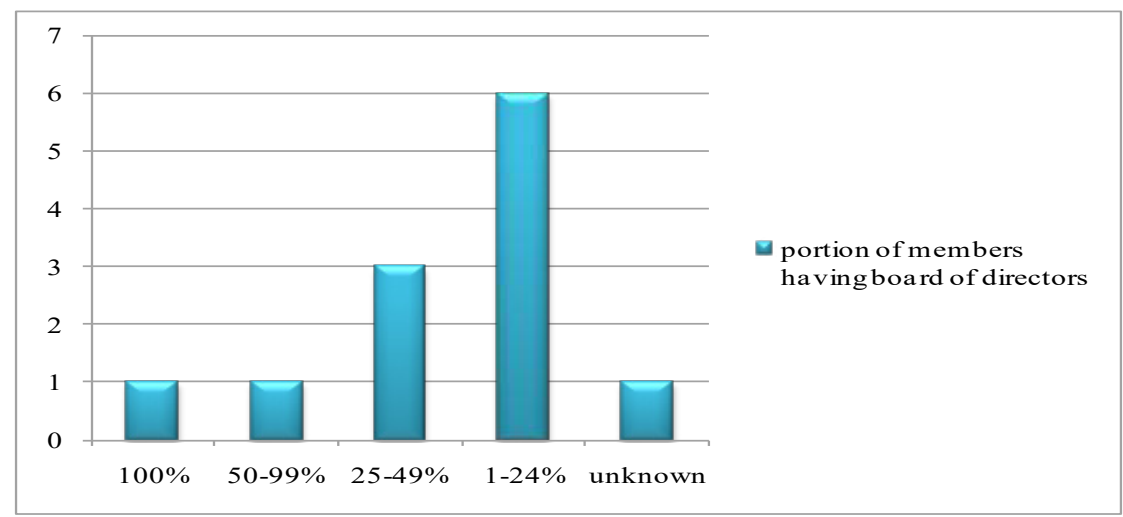


Figure 1: Proportion of companies having a board of directors

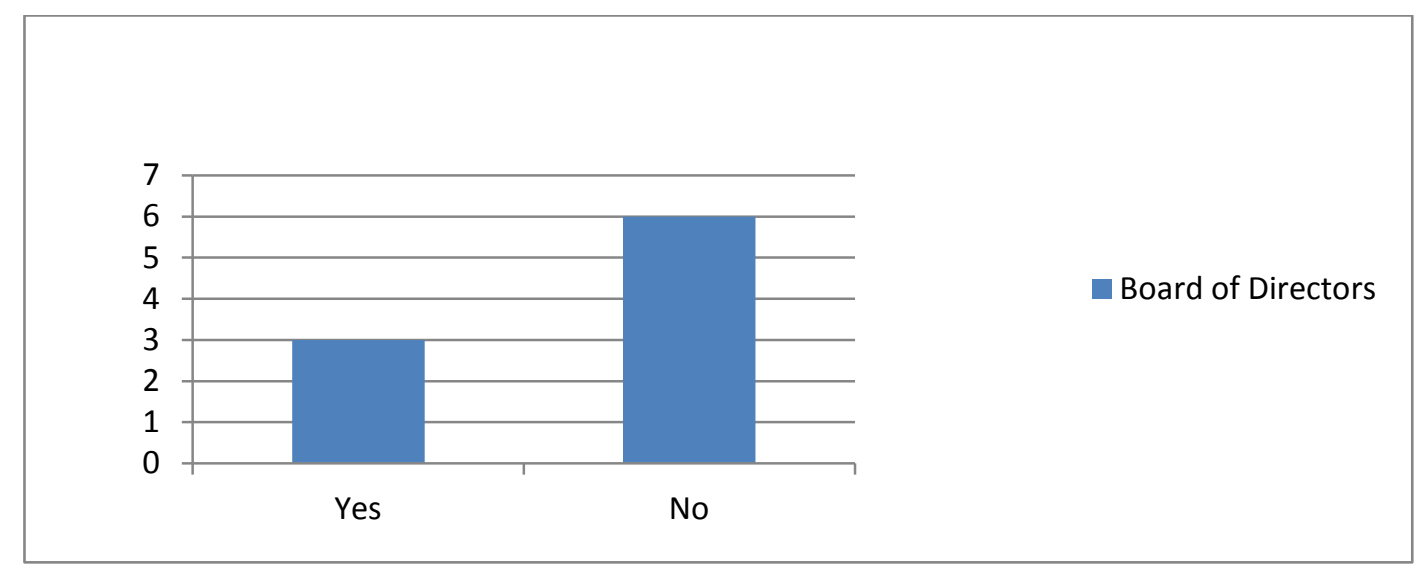

Figure 2: Proportion of small Businesses having board of directors

\section{Directors}

The small business owners did not appear to recognise that as the single 'owner/manager' they were also the 'Director' responsible under the Corporations Law.

\section{Qualifications of directors}

The qualifications of CEOs of the small business associations and small business owner/managers varied. Several of the Association CEOs had tertiary qualifications. Among the small business respondents, two had professional qualifications but most relied upon business or commercial experience.

\section{Diversity}

There were no female respondents and only one respondent saw any value in ethnic or gender diversity on boards.

\section{Succession plans}

Less than $25 \%$ of small business members have a succession plan. Where there was one, the plan was most likely to be directed towards the senior management or the owner manager position.

\section{Monitoring performance}

Two areas that could (a) promote good governance and (b) monitor results are a code of conduct and independent auditing. Half of the small businesses were reported to have a code of conduct.Only two of the twenty one respondents reported that their entities were audited.

\section{Disclosure}


Small corporations keep disclosure of their financial performance private and provide information to their accountants to meet taxation and financial requirements.

\section{Respondents' views on governance related difficulties experienced by small businesses}

The study explored what SMEs perceived to be their duties in relations to compliance with aspects of the Corporations Law and issues raised by good governance practices that included board structures, succession planning, monitoring and disclosing performance.

\section{Corporate registration}

Compliance with the corporate regulations for small businesses was in many cases left to accountants, due to the difficulties encountered by small businesses. They reported that the time frames for reporting were "too short" and that the penalties were disproportionate compared with an offence. ASIC was seen as too inflexible for small business management. The respondents felt that the language used by ASIC and ACCC was confused and convoluted. Further, that ASIC provided poor phone advice and was not tune with modern IT. In contrast, the Australian Taxation Office was now more "customer friendly".

\section{Directors Duties}

Directors of small businesses reported difficulties in relation to directors' duties. They reported Rules for the directors were difficult to understand but in most cases the responses indicated a lack of awareness of directors duties by owner/managers'. A good deal of concern was expressed about the level of liability/criminal sanctions regarding directors, ASIC assumptions that directors understand their responsibilities, too much accountability requirements. Although most reported that a board of directors was unnecessary, respondents pointed out that in any case their limited ability to fund directors could hardly attract high quality directors.

As a result, they proposed that the government should clarify and simplify their rules with regards to the directors' duties and educate the directors. Funding the industry associations could provide training to directors.

\section{Regulation}

Respondents reported several difficulties in relation to compliance with the regulation of small businesses. The main difficulty was that they lacked knowledge and understanding of the regulations, lack of appreciation of the difference between the owner/manager and the company as a separate entity, lack of understanding of what it means not to comply with directors duties and governance regulations. They respondents felt that because of a lack of skills in dealing with regulators, they were reliant on accountants or lawyers and the subsequently costs were involved.

Difficulties that were reported by the regulators were inappropriateness of regulation to small business, lack of understanding by ASIC of small business points of view resulting from poor communication, resulting in poor compliance, Failure of government to communicate efficiently with small corporations about corporate governance, the regulation and corporate governance requirements are intertwined and the difficulty by small businesses to capture the latest requirements.

Some of the solutions suggested were for the Government regulators to streamline registrations and invest in a regime to assist small business. Previous processes for change have never resulted in improvement, due to the fact that the government efforts are misplaced. They also said the ABR Blog 
looks good- lots of money has been thrown at it- but take up seems to be very low. Therefore there appeared to be a need for developing specific programs suitable for small businesses.

They also proposed that the law needs to be stabilised and consistent. For example, labour law and health and safety regulations are changing so frequently that it is very difficult for industry associations to keep up. They stated that there should be unified requirements between the States such as adoption of unified definitions in legislation, adoption of standard business reporting, and adoption of uniform hours among the states. Furthermore, they proposed streamlining the requirements of tax administration and other reporting requirements. They suggested that the Governments should improve communication with the industry and small businesses.

\section{Record Keeping}

Small businesses considered financial record keeping complex to understand and follow as well as time consuming, especially due to their lack of skills for preparing financial documents. As a result this task was left to their accountants, which was a cost.

They proposed to simplify the requirements of record keeping for small businesses and facilitate training of small businesses with techniques suitable for them to use for compliance purposes. They also proposed that the government should fund small business industry associations or professional associations to communicate the changes of regulations rather than letting small businesses bear the cost of keeping up to date or of non-compliance. They also suggested greater flexibility for small businesses when it comes to auditing issues, because reporting is not their core business.

\section{Difficulties incurred with different regulatory regimes}

Respondents reported that small businesses have major difficulties in regards to access to finance, tax administration, interest rates and anticompetitive practices. They also identified difficulties in relation to labour relations.

The respondents proposed that the federal government should provide more supportive export grants, State government should ease the paper work and employee superannuation and parental leave management could be handled through the tax office.

\section{Factors which inhibit or promote the performance of small business}

The respondents of this study reported factors that would inhibit or promote the performance of small Businesses. They stated that the performance of small business is impacted by various external factors that include taxation, the direction of regulation of utilities, and access to finance. They also reported internal factors that could promote performance were high levels of skills and knowledge by owner/manager/directors, their expertise in the use of information and communications technology (ICT), and ability to obtain information and advice. In addition to the above, emerging issues that will be important in the future were the environment, social networking and social responsibility.

\section{Conclusion}

Due to the importance of small businesses in the Australian economy, this study was conducted to understand the corporate governance and corporate regulation for small businesses. The views of the respondents were that there was a general agreement among the CEOs of small business associations that small business owner/managers were not aware of their legal obligations in regard to governance. For this reason they reported few difficulties with the regulation.

Compliance with legal obligations were managed by accountants and lawyers. Small businesses were apathetic in regard to complying with best practice governance. Corporate governance legislation that applied to all businesses was written with big business in mind, in language that was directed to accountants and lawyers and not understood by the small businesses. Therefore they found it difficult to understand corporate governance legislation. 
Several people sought more stability and less change in regulation, and, if there were changes, they wanted to be consulted and notified what the changes were. It was felt that the government should streamline the regulation in regard to small business and that previous efforts for change had been unsuccessful because the efforts were misdirected and resulted in few improvements.

The major problems with governance regulation which were identified by small business were their lack of ability to influence government by small business, lack of knowledge of the regulations by small business, lack of understanding of the regulations by small business, lack of appreciation of the difference between the owner/manager and the company as a separate entity, lack of understanding of what it means not to comply with directors duties and governance regulations, lack of skills in dealing with regulators and reliance on accountants or lawyers and the costs involved.

Furthermore, regulation was inappropriate for small businesses due to lack of understanding by ASIC of small business resulting in poor communication and poor compliance, The regulation requirements need to be stabile and consistent, unified between the States (i.e. adoption of similar definitions in legislation, standard business reporting, and uniform hours among the states), streamlining the requirements of tax administration and other reporting requirements. Despite the lack of knowledge, or because of it, respondents wanted government regulators to improve communication with the industry associations and small businesses.

The study confirmed that agency theory, the traditional theory used to justify the introduction of good corporate governance practices, was not necessarily appropriate for small corporations. Further research is required to develop a more relevant, better suited explanation to justify the appropriate regulation of the sector. Such regulation needs to bear in mind the following points:

- The fact that small corporations are time and resource stretched;

- They are often family based

- The potential role of peak bodies and associations as 'go- betweens between firm and regulator;-and

- Determining how the optimal regulatory model can best be communicated to small corporations.

These important questions are the subject of ongoing and further research. In essence, the critical question is how in the $21^{\text {st }}$ century can there be a cooperative partnership style approach underpin the work of the key stakeholders (firm, peak body, the public and the regulator) in the regulated market?

\section{References}

Adams, M. (2010) 20 Year snap-shot of the developments in the regulation of small corporations. Journal of Business Systems Governance and Ethics 4(4): 7-23.

Armstrong, A., LI, Y. Heenetigala, K., Clarke, A. et al (2011) 'Developing a Responsive Regulatory System for Australia's Small Corporations: Governance for Small Business'. Melbourne, Victoria Law School. ISBN 978-1-86272-692-5

Armstrong, A. (2004) Commentary on Codes of Corporate Governance. In . Armstrong, A. and Francis, R. (Eds) Corporate Governance: An. Introduction to Corporate Governance Sydney, Standards Australia International.

Australian Corporations and Securities Legislation. (2011) ASIC Act 2001. Sydney, CCH.

Banks G. (2006) Reducing the Regulatory Burden: the way forward. Inaugural Public Lecture, Monash Centre for Regulatory Studies. Melbourne. 17 May. www.pc.gov.au

Burgess, S. \& Hill, R.( 2004) 'Corporate Governance in Small Business'. In A. Armstrong and R. Francis (Eds). Applications of Corporate Governance, Sydney, Standards Australia international Ltd.

Burgess, S. Sellitto, C. and Karansios, S. (2009) Effective Web Presence Solutions for Small Business: Strategies for Successful implementation,. New York, information Science Reference. 
Chittenden, F, Kkauser, S and Poutzioris, P. (2003) Tax regulation and small business int he USA, UK, Australia and New Zealand. International Small Business Journal, 21(1), 93-115.

Clarke, A. D. (2007) Australian Corporate Governance and SMEs: The forgotten Stakeholders? ABLR, 7-17.

Clarke, T. E. (2004). 'Theories of Corporate Governance.' New York, Rutledge.

Clarke, T. and A. Klettner (2010). "Governance issues for small business." Journal of Business Systems Governance and Ethics 4(4): 23-41

Deighton-Smith, R. (2008). "What do we mean by 'Rethinking regulation?'." Australasian Journal of Public Administration 67(1): 41-56.

Eisenhardt, K.M.(2004) Agency Theory: An Assessment and Review. In Clarke, T. E. (Ed). Theories of Corporate Governance. New York, Routledge.pp. 78-92.

Fama, E. F. and M. C. Jensen (2004). "Separation of Ownership and Control". In T. Clarke (Ed). Theories of Corporate Governance. New York, Rutledge.

Fehlberg, B.Women in 'Family' Companies (1997) Companies and Securities Law Journal 348, p. 360.

Francis, R.D. and Armstrong, A. (2009) Meetings, Morals and Manners. Australian Journal of Corporate Law 23(1): 94-114.

Green, RA (2002) Recent developments in federal regulatory policy. The Journal of Small and Emerging Business Law Fall, 607-115.

Kanthapanit, C. Armstrong, A. and Tippett, J. (2010) Determinants of minority shareholder rights in the Thai banking sector Determinants of minority shareholder rights in the Thai banking sector. Paper presented to the 13th International Business Conference, 2224 November 2010

Miller, G. (2010) Developing a small business regulatory system. Journal of Business Systems Governance and Ethics 4(4): 1-6.

OECD (1997) The OECD Report on Regulatory Reform Synthesis, Paris, Organisation for Economic Co-operation and Development.

Romano, C., \& Smyrnios, K. (1996) Accounting Honours programmes: Perceived benefits. Accounting Education, 5(3), 233-244.

Spender, J.C. (1997) Publicly Supported R\& D Projects: The US's Advanced Technology Program, Science and Public Policy, 21 (4), 45-52.

Wiltshire Committee (1971 Report of the Committee on Small Business. The Government Printer of Australia, Canberra, Australia. 